STUDIA PRAWNO-EKONOMICZNE, T. CXIII, 2019

PL ISSN 0081-6841; e-ISSN 2450-8179 $\quad$ s. 299-315

https://doi.org/10.26485/SPE/2019/113/17

Stanisław RUDOLF*

iD https://orcid.org/0000-0002-3292-3243

\title{
CONDITIONS FOR THE DEVELOPMENT OF EMPLOYEE REPRESENTATION IN CORPORATE GOVERNANCE IN EUROPEAN COUNTRIES
}

\begin{abstract}
Background: Employee representation in corporate governance bodies already has an established position in European countries. It refers to the two-tier model of governance, with the supervisory board and management board rather than the one-tier model with a board of directors. The development of such representation is influenced by the EU authorities implementing long-term processes to harmonize solutions in member states. Such representation has also been developed in the Nordic countries under the influence of democratization processes. However, in several countries, the processes of limiting such representation can be observed, and this is related to the political conditions (the strengthening of right-wing parties) and a difficult economic situation caused by the 2008 financial crisis.

Research purpose: The purpose of the study is to identify factors that affect changes in the scope of such representation, as well as to determine their effectiveness based on selected case studies. Methods: In order to achieve the research objective, a critical analysis of the subject literature and appropriate legal regulations was used. The analysis covered, among others, texts published in renowned journals concerning industrial relations (European Journal of Industrial Relations, Industrial Relations Journal), while problems from the legal perspective (Journal of Comparative Law Study) were also analyzed.

Conclusion: It can generally be stated that conditions in recent decades have fostered the development or strengthening of employee representation in corporate governance bodies. The attempts to harmonize employee representation in governance made by the EU authorities should be assessed positively, although their formal results are relatively modest and are limited primarily to the European Company Statute. Positive changes can also be observed in the Nordic countries, where the existing conditions, including primarily the democratization processes, forced the modification of the one-tier model by creating the possibility of including employee representation on the board of directors. At the same time, pressure can be observed in many countries to limit or eliminate employee representation in governance.
\end{abstract}

Keywords: corporate governance, employee representation, corporate governance models.

JEL classification: G34, M54

* Prof. dr hab., WSB University in Gdańsk, Faculty of Finance and Management; e-mail: srudolf@wsb.gda.pl 


\section{Introduction}

The last few decades have brought major changes in corporate governance systems. The largest, however, occurred in the last 15-20 years. ${ }^{1}$ During this period, more attention was paid to the functioning of corporate governance. It was realized that governance could become an important factor in improving company effectiveness, and thus economic growth, as well as raising the competitiveness of the entire economy. Appropriate corporate governance allows for the better use of capital held by companies, increases the trust of both domestic and foreign investors, and affects the location of foreign direct investment. Governance may also make the company take into account the interests of the state, region, or local community in its activity rather than be guided solely by its own interests. Research shows that investors are more willing to buy shares in companies with high-quality corporate governance. ${ }^{2}$

It is the growing concern for the quality of governance that has made it subject to evolutionary processes. Such processes are forced, on the one hand, by growing competition, and on the other hand, by the changing conditions of the companies' activity. Increasing competition, on both the national and international scale, results in increasing demands regarding the performance of companies, the rationality of their actions taken, but also their transparency, resilience to crises, etc. Corporate governance may support the fulfillment of these requirements, but only when it is adapted to the existing conditions and supports the company in achieving its goals. Due to changes in these conditions, the system of governance must also change.

The changes in corporate governance systems were accompanied by changes in employee representation in corporate governance bodies. Such representation is known as indirect employee participation. ${ }^{3}$ Employees choose their representatives to participate in decision-making on their behalf, together with other members of these bodies. Employee representatives are mainly in the two-tier corporate governance model, with the supervisory board and the management board. It is in the supervisory board where, due to its control and supervisory rather than decision-

Cf. M. Gold, Taken on board: An evaluation of the influence of employee board level representatives on company decision-making across Europe, European Journal of Industrial Relations 2011/15/1.

2 J. Jeżak, Lad korporacyjny. Doświadczenia światowe i kierunki rozwoju, C.H. Beck, Warszawa 2010, pp. 12-14.

3 S. Rudolf, K. Skorupińska, Bezpośrednie formy partycypacji pracowniczej. Polska na tle starych krajów Unii Europejskiej, Wydawnictwo Uniwersytetu Łódzkiego, Łódź 2012, pp. 16-19. 
making nature, employee representation is more readily accepted by employers. In many European countries, such representatives make up one-third of the board, and less often, they make up half. They usually have the same rights and responsibilities as other board members. In the West, they are usually called worker directors. However, exceptions include employee representation on management boards.

Employee representatives are less common in the one-tier corporate governance model, where there is no division into supervisory and decisionmaking bodies. The board of directors performs both supervisory and decisionmaking functions. Because of this, employee representatives are rare. Managers are generally against such participation because of the operational nature of this body. In some countries, however, there are intermediate solutions between the one-tier and two-tier models, and they concern more than just the issue of employee participation in governance. ${ }^{4}$

Employee representation in corporate governance bodies, regardless of whether it is a two-tier or one-tier model, has raised much controversy. ${ }^{5}$ The discussion on this subject concerns both its political, ideological, and economic aspects. This form of employee participation has both strong supporters and opponents. Its supporters point to the benefits that such representation brings to both the company and its employees. They emphasize ${ }^{6}$ that long-term employees are a special kind of human capital, bearing residual risk similar to the owners, and thus they deserve proper representation at the board level. Such representation can also bring many benefits to the employees. They can actively monitor management activities, protect employee interests, and provide a channel for the flow of information between employees and management. ${ }^{7}$

4 More information on employee representation in corporate governance can be found in: S. Rudolf, Udziat przedstawicieli załogi w organach spótki, in: D. Dobija, I. Koładkiewicz (red.), Ład korporacyjny. Podręcznik akademicki, Oficyna a Wolters Kluwer business, Warszawa 2011, pp. 358-386; A. Szymańska, P. Włodarczyk, Przedstawicielstwo pracownicze w radzie spółki w krajach członkowskich Unii Europejskiej, Studia Prawno-Ekonomiczne 2012/LXXXVI; K.P. O'Kelly, Summary Report and Summing up, in: K.P. O'Kelly (ed.), The Role of Worker Directors in the European Union, European Foundation for the Improvement of Living and Working Conditions, Dublin 1996.

5 W. Njoya, Employee Ownership in the European Company: Reflexive Law, Reincorporation and Escaping Co-determination, Journal of Corporate Law Study 2011/12/2, p. 274.

6 L. Fauver, M.E. Fuerst, Does Good Corporate Governance Include Employee Representation? Evidence form German Corporate Boards, Journal of Financial Economics 2006/82, pp. 673-701.

7 J. Roberts, E. Van den Steen, Human Capital and Corporate Governance, in: J. Schwalbach (ed.), Corporate Governance: A Volume in Honor of Horst Albach, Springer Velag, Berlin 2000. 
The conducted research indicates a significant dynamics of changes in employee participation in governance bodies. ${ }^{8}$ The aim of the study is to identify factors that affect the scope of such representation, as well as to determine their effectiveness based on selected case studies. Therefore, the following will be analyzed: the impact of the EU on the unification of the scope of such representation in the member countries, the impact of the democratization of labor relations on the expansion of such representation based on the example of Nordic countries, and the impact of political and economic conditions (economic crises) on such changes. In order to achieve the research objective, a critical analysis of the subject literature and appropriate legal regulations was used.

\section{Attempts to harmonize employee representation in governance in EU countries}

Employee participation in governance bodies is difficult to consider without analyzing company law legislation. The authors agree ${ }^{9}$ that since the beginning, i.e., since the $1950 \mathrm{~s}$, actions have been taken to harmonize company law, including the harmonization of employee participation in corporate governance bodies. Initially, the situation was quite favorable for such harmonization. Until 1972, it had been supported by three of the then six member states, namely France, Germany, and the Netherlands. Harmonization would standardize employee rights in the member countries in the important areas of strategic decision making by companies. However, the level of determination was not sufficient to achieve this goal.

Currently, the situation is very different. Subsequent countries that joined the EU brought their own employee representation systems, often very different from the others. All of this calls into question the effectiveness of these harmonization processes in the EU. It often took decades to shape national corporate governance. Thus, it was the result of long-term evolution and a clash of social and economicpolitical views. At the same time, these systems are deeply embedded in the national institutional framework. Harmonization processes undertaken in these conditions must be strongly resisted mainly by employers and their organizations, but also by some trade unions or political parties.

${ }^{8}$ A. Conchon, Are employee participation rights under pressure? Trends at national and EU level, European Economic, Employment and Social Policy 2012/7.

${ }^{9}$ L. Enriques, A Harmonized European company law. Are we there already?, International and Comparative Law 2017/66/3; M. Gelter, EU company law harmonization between convergence and varieties of capitalism, 2017, https://ssrn.com/abstract-2977500 
Great Britain was definitely against such harmonization, which effectively inhibited such processes. This is illustrated by the example of the European Social Charter, which was signed by all member countries except for Great Britain in Strasbourg in 1989. The Charter indicates the right of employees to participate in corporate governance. It was included in the chapter entitled "Information, taking into account the opinions of employees, and cooperation." ${ }^{10}$ In the subsequent two years, the way of implementing the Charter was discussed. Due to the opposition from Great Britain, it was not included in the Treaty of Rome. Its principles in the form of the Protocol and Agreement on social policy were annexed to the Maastricht Treaty concluded in 1992. However, the Charter was not binding, and its rights are not subject to appeal.

At the same time, attempts were being made to harmonize employee representation by law at the EU level. At least two such attempts can be referred to. The first one was undertaken by the European Commission in 1970, i.e., at a time when the European Economic Community numbered six countries. At that time, the draft statute for the European Company (Societas Europea in Latin - SE) was drawn up, which was based on the German law model. Subsequently, work on the statute was suspended, mainly due to opposition from Great Britain, which considered such a proposal to be unacceptable. The work was resumed after the establishment of the Single European Market in 1986, which is the next stage of the European economic integration. This act guaranteed the so-called free movement of capital, goodsservices and persons.

In 1989, the Commission published an amended draft regulation and a draft directive on the SE. Negotiations continued until 2001, when the relevant regulations contained in Directive 2001/86 and the Council Regulation of 8 October 2001, No. 2157/2001 on the Statute for the European Company were adopted. Such detailed provisions on participation are justified because SEs arise from entities located in different countries, where different participation systems apply. Pursuant to the directive, the scope of employee participation in the SE cannot be lower than in the countries where the entities form a company. National laws developed on its basis may partially relax participation requirements. However, the directive provides that an SE cannot obtain legal personality without the required forms of participation. ${ }^{11}$

10 Karta Socjalna Wspólnoty Europejskiej, www.ptps.org.pl/old_siteu_miedzynarodowe.php?usta wodawstwo_id=14, 1989

11 German legislation had a significant impact on solutions regarding employee representation in corporate governance in the SE (J. Wratny, Partycypacja pracownicza. Studium problemów 
Participation rules in the SE should be developed in parallel with the process of its creation. A starting point is the announcement of the intention to establish an SE. The management body of the company should enter into negotiations with a "special negotiating team" representing employees in the entities forming the SE. Such negotiations should end with signing an agreement, which should specify, inter alia, the scope of participation, the rules of appointing and the functions of the representative body, the method of providing information and consulting, the scope of financing the body's activities, etc. A special negotiating team may propose another solution, giving up the idea of appointing a representative body. ${ }^{12}$ It is worth emphasizing that it is the SE stakeholders that determine the form of employee representation in governance, and thus, it can be both a two-tier and a one-tier system. This solution differs from previous solutions of this kind, where the legislation of a given country imposed a system of employee participation in supervisory bodies.

Procedures for establishing an SE are very complex; therefore, they are probably rare in many countries. According to ETUI data, in 2014 there were 2125 companies, but only 289 of them conducted business activity and employed over five people (so-called normal companies). Only such companies had regulations on employee representation in governance. Other companies are those that did not employ people, inactive companies, etc. Most normal companies were established in Germany (138), the Czech Republic (66), France (13), the Netherlands (13), and Austria (10). ${ }^{13}$ The two-tier corporate governance model dominates $(81 \%)$ in these companies. ${ }^{14}$ This is largely due to the governance system in the country where the SE was registered, but this is not, as already mentioned, obligatory. It is noteworthy that in both Germany and Austria, where the two-tier model applies, most SEs chose a one-tier model. This may indicate a search for an alternative to the model in force in these countries.

Thus, the SE is becoming a new type of company with a very flexible system of employee representation in governance bodies. Admittedly, the period

w warunkach transformacji gospodarczej, Instytut Pracy i Spraw Socjalnych, Warszawa 2002, pp. 28-29).

12 M. Gladoch, Uczestnictwo pracowników w zarządzaniu przedsiębiorstwem w Polsce, Wydawnictwo Dom Organizatora, Toruń 2008, pp. 272-276.

13 In Poland, only two SEs have been established so far, but both of them do not satisfy the criteria of normal companies. No company of this type has been established so far in Bulgaria, Croatia, Greece, Romania and Slovakia.

14 A. Giedrowicz-Niwińska, Udziat pracowników w nadzorze korporacyjnym $w$ spółce europejskiej, Institute of Economic Research, Working Paper 2015/33, pp. 6-7. 
of several years since the adoption of the directive has not brought their dynamic development, but recent years indicate a significant acceleration of this process. It is worth highlighting that the SE contributes to the popularization of employee representation in governance bodies also in countries where such representation does not occur. Great Britain is an example where companies forming an SE with German companies and registered in Germany, for example, mostly adopt the two-tier model in force in Germany. This means that the representatives of British employees are on the supervisory boards of SEs registered in Germany.

The limited pace of establishing SEs is undoubtedly due to the aforementioned complex company formation procedure. It seems that regulations on employee representation in governance bodies are an important restriction. Experience shows that companies clearly avoid employee representation; hence, only $13 \%$ of registered SEs have employee representation in governance. This is partly due to the costs incurred by the employer, both when negotiating agreements as well as the costs of the functioning of such representation (the costs of training, remuneration for board members, preparing information, translations, etc.). These restrictions indicate the need for new regulations that should accelerate the formation of a SE.

The above solutions aimed at harmonizing legislation at the EU level are applied on a voluntary basis and have not yet attracted wider interest. The other attempt concerned the unification of employee representation throughout the EU on an obligatory basis. A provision on this subject was included in the draft fifth directive of 1972 on the structure of joint-stock companies. Its preamble paid attention to differences in employee representation on boards in individual member countries. It proposed the elimination of these differences because they constitute a barrier to the application of Community regulations on the reorganization of companies. Of the two models - the two-tier (called German) and the one-tier corporate governance models in member states - the two-tier model is proposed, with emloyee representation making up at least one-third of the members of the supervisory board in companies employing at least 500 people. The second proposal therein was based on the Dutch system, and it assumed that changes would be made to the supervisory board on the basis of co-option, with a right to veto of employee organizations. ${ }^{15}$

In 1983, i.e., after more than ten years of lively discussion on the issue, a new, clearly amended project was presented. It provided for, among others,

15 W. Kolvenbach, Handbook on European Employee Co-management, Kluver Law and Taxation Publisher, Deventer, Boston 1987, pp. 141-150. 
a negotiable employee representation option, and the company size threshold increased to 1,000 employees. Due to the unanimity requirement for the Commission decision, the project was blocked by Great Britain and finally withdrawn in 2004. However, this initiative played an important role in the ongoing discussion on this issue, especially in Great Britain and Italy. At the same time, it contributed to the stimulation of the European labor movement.

Summing up this part of the discussion, it can be stated that attempts to harmonize employee representation in corporate governance in EU countries have failed. The solutions still used in individual countries differ significantly. Changes that have taken place in this respect are mainly determined by economic and political factors. The EU did not use the previously existing possibilities for such harmonization and limited itself to extremely complex solutions contained in the European Company Statute. It can be assumed that due to the voluntary nature of these companies and the extremely complex formation procedure, their scope will remain marginal. At the same time, the observed processes of corporate governance integration, regarding, inter alia, the codes of good practice, occur under the influence of increasing competition and the facilities for business created by governments, and they are the result of EU policies only to a small extent.

\section{Employee representation in the Nordic governance model}

The corporate governance model in the Nordic countries differs from both the Anglo-American one-tier model and the Continental European two-tier model. ${ }^{16}$ It can be located between these models because it is a combination of the two. It should be added that the term "Nordic model" does not mean that identical elements of this model can be found in all Nordic countries. This term refers to the overall structure of governance that can be found in countries such as Sweden, Norway, and Denmark. A common feature of the Nordic model is employee representation on the board. On the one hand, the functioning of the board resembles a board of directors because it is responsible for all matters related to corporate management, including its strategy, organization, company finances, risk management, and internal control, while day-to-day management is entrusted to the Chief Executive Officer (CEO). However, these countries differ in many detailed solutions. In the further part of the discussion, we will focus on employee representation in corporate governance in Sweden and Norway.

16 S. Thomsen, The Nordic Corporate Governance Model, Management and Organization Review 2016/12/1, pp. 189-204. 
Sweden is a country with a long tradition of social democracy. It is also among the countries with the highest level of employee membership in trade unions. ${ }^{17}$ Therefore, it may be surprising that the presence of employee representatives in corporate governance bodies happened much later than in continental Europe - in the mid-1970s. Employee representation in governance was introduced by the Act of 1973, but participation became common only in 1976. The adopted solution was severely criticized by both right-wing and leftwing forces. At most, both right-wing politicians and employers' organizations agreed to voluntarily invite employee representatives to board meetings. The left wing was also opposed to such a solution and saw collaboration with the capitalist system in such representation.

Pursuant to the above Act, in companies employing at least 25 people, employees have a right (but not an obligation) to select two representatives for the board of directors. Their number increases to three in companies employing over 1,000 people. The Act also provides that the number of employee representatives may not be greater than the number of other board members. Thus, employee representatives can never constitute a majority on the board. It should be added that the Swedish board of directors usually has from five to nine members. ${ }^{18} \mathrm{~A}$ decision to delegate employee representatives to the board is made by local trade unions, and this is specified in the relevant provision in the collective bargaining agreement.

Employee representatives on the board have the same rights and obligations as the other board members; they also have the same responsibility for the decisions taken it takes. Their votes during voting count as the votes of board members elected by shareholders. The differences between them mainly reduce to the way they are paid. As many as two-thirds of employee board members do not receive any remuneration in this respect. Only about $8 \%$ of them receive remuneration at the level of other board members, while the others receive some compensation for their work on the board. ${ }^{19}$

17 The level of the organization of employees in trade unions remained at around $80 \%$ for decades. Only after 2000 it fell slightly to 65-70\% (L. Hogedahi, K. Kongshoj, New trajectories of unionization in the Nordic Ghent countries: Changing labour market and welfare institutions, European Journal of Industrial Relations 2017/23/4, pp. 365-380).

18 T. Berglund, M. Holmen, R. Rana, Causes and Consequences of Employee Representation on Corporate Boards, paper presented at the conference "Twenty Years after Cadbury, Ten Years after Sarbanes-Oxley: Challenges of Corporate Governance”, University of Bath 2013, p. 4.

19 Workers' participation at board level in the EU - 15 countries, Reports on the national systems and practices, Hans Bockler Foundation/European Trade Union Institute, Brussels 2004, p. 118. 
The opinions of employers on employee representation on the board of directors are divided in Sweden. ${ }^{20}$ Some companies support this solution, indicating its many positive results, while others evaluate it critically, presenting numerous adverse consequences of such representation. It should be added that only half of Swedish companies authorized to delegate representatives to the board can find such representation. One reason for such a situation may be the strong position of trade unions, which do not always regard additional representation as necessary.

The above controversy, as well as the interest in the Swedish model of governance among authors from countries with a one-tier model of governance, have made it the subject of numerous empirical studies. ${ }^{21}$ In light of the research, employee representation in the Swedish governance system should be generally positively assessed. Their presence on the board generally offers companies both social and economic benefits. Managers view employee representatives as a valuable resource for the company. In their opinion, employees have a better understanding of the decisions taken by the board; it also facilitates the implementation of difficult decisions. At the same time, negative reviews were rare. It is worth emphasizing the flexibility of the Swedish governance system. Decisions on employee representation were left to employees and their trade unions. Research indicates that employees are delegated to the board mainly in the companies where they can play a role, where their preparation is relevant to the problems which their decisions are related to. They are rarely present in companies that operate on international markets, with foreign board members, and where risky decisions are made.

Another type of employee representation in corporate governance is observed in Norway, ${ }^{22}$ where a one-tier governance model applies. The board is clearly different from a typical board of directors, however, and the difference is not limited to the presence of employee representatives. The governance structure in this country depends on company size. In companies with up to 200 employees, it consists of the general meeting of shareholders and a board. Two-thirds of the board members are elected by shareholders at the general meeting. Due to the recommendations of the codes of good practice, most of them are independent members, i.e., from outside the company. The remaining board members (one-third) are elected by employees.

20 P. Lekvall, The Nordic Corporate Governance Model, SNS Forlag, Stockholm 2014.

21 K. Levinson, Employee representatives on company boards in Sweden, Industrial Relations Journal 2001/32, pp. 266-274; T. Berglund, M. Holmen, R. Rana, op. cit.

22 S. Ekern, Corporate Governance system in Norway, Corporate Governance, Winter 2015/2016. 
There is a more complex governance structure in larger companies with more than 200 employees. In this case, an additional body appears, called the corporate assembly. Two-thirds of its members are elected by shareholders at the general meeting, while the remaining one-third are elected by employees. The task of this body is to support the board in its activities. In this case, two-thirds of board members are elected by the members of the corporate assembly on the part of shareholders. Employee representatives in the corporate assembly may request the election of one-third of board members by and from among employees.

One cannot fully agree with Ekern, ${ }^{23}$ who believes that the governance structure presented above resembles the two-tier model. Although the Norwegian board performs both supervisory and control functions, it is also an important decision-making body. The scope of its powers is determined by the general meeting of shareholders, and it is usually very broad. According to this author, the function of the company's management board is performed by the Chief Executive Officer (CEO). However, other similarities to the two-tier model can be indicated. The same person cannot simultaneously be the CEO and chairman of the board.

It is worth emphasizing that Norway was the first country where the Law on Gender Equality in governance bodies was passed in 2002. The participation of women or men may not be lower than $40 \%$. The participation of women in governance bodies in public companies has been at such a level since 2008. ${ }^{24}$

To sum up this part of the discussion, it can be stated that the decades of democratization processes in the Nordic countries, including the democratization of labor relations, led to the establishment of employee representation on boards of directors. The credit goes mostly to trade unions, whose position is high there, and definitely higher than in other European countries. Sweden has had such representation for over 40 years, and there is no indication that its rules will change. In Norway, it operates on the basis of the Act on Joint Stock Companies of 1997. Due to the weaker position of Norwegian trade unions compared to the Swedish ones, a decision on such representation is taken by the company's employees or their representation. The Norwegian system has not yet been thoroughly studied, but there are indications that it may prove more effective than the Swedish one. ${ }^{25}$

23 Ibidem, pp. 9-10.

24 C.A. Mallin, The Nordic Corporate Governance Model, Oxford University Press, Oxford 2010, p. 140.

25 The situation is different in Finland, where employee representation on the board is not compulsory. As a result, less than $1 \%$ of companies have such representation (S. Thomsen, op. cit., p. 189). 


\section{The impact of political and economic conditions}

The controversy about employee representation in governance was further exacerbated by the financial crisis that began in 2008 and the effects of which are still felt. This crisis strengthened the opponents of employee representation in general, and their participation in corporate governance in particular. As a result, it indirectly contributed to limiting or eliminating legislation on employee representation on the board. Such trends are related to, among others, privatization, which intensified in many countries as a result of the crisis.

In some countries, legislation guarantees employee representation in governance only in state-owned companies. This means that privatizationin many countries deprives employees of this right. Ireland is an example where several large state-owned companies have recently been privatized. A similar situation occurred in Malta. Probably due to the difficult economic situation of these countries, their trade unions did not counteract this too intensely. Banks, which force indebted companies to limit or eliminate such representation, also contribute to reducing employee representation on boards, as happened in Spain. ${ }^{26} \mathrm{~A}$ change in the governance model from a two-tier to a one-tier model may also lead to the reduction of employee representation in governance. Such changes were made in Hungary and Slovenia. In the former, the governance model changed in 2006. In this way, employees were deprived of such representation on supervisory boards (in the two-tier system).

Employee participation is currently much narrower, based on an agreement between the board of directors and the works council. In Slovenia, the governance model also changed in 2006. Employee representatives are now on the board of directors, but under much worse conditions. Employee representatives used to constitute from one-third to a half of the supervisory board; in the one-tier model, their share on the board of directors decreased to $20-27 \%$. The governance model also changed in the Netherlands, where the one-tier model has been in force since 2012. In this case, however, employee rights have not changed. ${ }^{27}$

In Poland and the Czech Republic, attempts have been made to eliminate or seriously limit legislation on employee representation on boards. In January 2010 in Poland, the Ministry of the Treasury presented the Draft Act on the Rules for

26 N. Kluge, S. Vitols, The crisis: catalyst for stronger worker participation in corporate governance, 2010, http//www.worker-participation,eu/About-WP/Publications/SEEutope-report

27 A. Conchon, Board-level employee representation rights in Europe. Facts and Trends, European Trade Union Institute, Report 121, Brussels 2011, pp. 24-25. 
Exercising Certain Powers of the Treasury ${ }^{28}$ where it proposed changes regarding employee representation on the supervisory boards of privatized companies. If two seats on a 5-member supervisory board had been intended for employee representatives so far, the project did not provide for such representation at all. This project was criticized by trade unions, both NSZZ Solidarność and OPZZ, and was rejected after the discussion. Some attempts to limit such representation have also been made in the Czech Republic. ${ }^{29}$

At the same time, proposals were submitted to expand or strengthen employee representation on boards. Such proposals were made mainly by leftwing parties and the majority of trade unions. Such proposals were contained in the program of the French Socialist Party, among others. The German SPD submitted proposals to extend legislation on this issue, for example, ${ }^{30}$ by establishing a list of key decisions in the company that require the consent of the supervisory board or lowering employment thresholds applicable to particular types of representation. These proposals were discussed; however, they were not implemented.

It is worth paying attention to the position of trade unions in individual countries on the issue of employee representation in governance. As mentioned before, in Ireland and Malta, unions did not protest against limiting employee representation in governance, and this was due to the economic situation of these countries. Trade unions were more active in countries such as Norway, Luxembourg, France, Germany, and the Netherlands. They put forward proposals for certain adjustments to the existing legislation towards lowering the existing thresholds for the size of the company to which employee representation applies (Norway, Luxembourg) or expanding such representation (the Netherlands). They also called for the extension of existing legislation to public companies if only state-owned companies were already subject to it. ${ }^{31}$

Other reasons led to the discussion about employee representation in Great Britain. In this country, which is traditionally the biggest opponent of the institutional employee representation in corporate governance, ${ }^{32}$ the share

28 Draft Act on the Rules for Exercising Certain Powers of the Treasury, 2010, http://bip.msp.gov. pl/portal/bip/115/3516/Projekt_ustawy_o_zasadach_wykonywania_niektórych_uprawnien Skarbu_Panstwa.html

29 A. Conchen, Board level..., p. 23.

30 Ibidem, pp. 25-26.

31 Ibidem, pp. 26-28.

32 It should be mentioned that in the past, there were attempts to include employee representatives in corporate governance bodies. This took place in the 1970s, when the representatives of 
of employee representatives in the remuneration committees appointed by the boards of directors has increased unexpectedly. The 2010 report prepared by the Secretary of State for Business "invite[s] views on whether independent members or employee representatives on remuneration committees would provide a helpful, fresh perspective and encourage greater challenge; as well as the potential risks and practical implications of such measures." ${ }^{33}$ Additionally, the TUC, the English Trades Union Congress, recommends that employees should be represented on remuneration committees through their trade unions.

\section{Conclusion}

It can generally be stated that conditions in recent decades have fostered the development or strengthening of employee representation in corporate governance bodies. Although the actions taken in this direction were not always successful, the result turned out to be positive. The attempts to harmonize employee representation in governance made by the EU authorities should be assessed positively, although their formal result is relatively modest and is limited primarily to the European Company Statute. However, it should be remembered that the proposals submitted were aimed not only at unifying, but also at expanding employee representation. The proposals were based on the German model, which represented by far the widest scope of such representation. In Germany, most employees are employed in companies with a 50\% share of employee representatives (including trade unions) on boards. ${ }^{34}$ Discussions on this issue certainly influenced the choice of the German model by many new EU members.

Positive changes could also be observed in the Nordic countries, where the existing conditions, including primarily democratization processes, forced the modification of the one-tier model by creating the possibility of including employee representation on the board of directors. It is worth noting that this is not an obligatory solution. A decision about it is made by trade unions or the

employees (trade unions) could be found on the boards of large companies with a majority of state capital. However, this solution did not meet expectations and after a few years (sometimes more than a decade) it was abandoned.

33 A. Conchen, Board level..., p. 50.

34 P.-Y. Gomez, P. Wirtz, Successfully mobilizing for employee board representation: Lessons to be learned from post-war Germany, Journal of Management History 2018/24/3, pp. 262-281. 
company's employees. Such a solution seems to be appropriate in the conditions of the mature, civil society in the Nordic countries.

At the same time, pressure can be observed in many countries to limit or eliminate employee representation in governance. At the national level, it is influenced by two factors, namely political conditions (right-wing parties) and, to some extent, the economic situation. In both cases, the 2008 financial crisis proved to be significant. As a result, privatization processes accelerated, which removed employees from governance, as the case study of Greece or Malta shows. Changes in the corporate governance model from a two-tier to a onetier model are also moving in the same direction, combined with the reduction of employee representation on boards of directors, compared to supervisory boards. ${ }^{35}$ However, there are many indications that this type of phenomenon is temporary, as it was before. It should be expected, therefore, that after the economic and political situation has stabilized, employee representation on boards will continue to strengthen.

\section{References}

\section{Legislation}

Council Directive 2001/86/EC of 8 October 2001 supplementing the Statute for a European company with regard to the involvement of employees.

Draft Act on the rules for exercising certain powers of the Treasury, 2010, http://bip.msp.gov.pl/ portal/bip/115/3516/Projekt_ustawy_o_zasadach_wykonowania_niektórych_uprawnien_ Skarbu_Panstwa.html

\section{Studies}

Berglund Tom, Holmen Martin, Rana Rakesh, Causes and Consequences of Employee Representation on Corporate Boards, paper presented at the conference, "Twenty Years after Cadbury, Ten Years after Sarbanes-Oxley: Challenges of Corporate Governance", University of Bath 2013.

Conchon Aline Are employee participation rights under pressure? Trends at national and EU level, European Economic, Employment and Social Policy 2012/7.

Conchon Aline, Board-level employee representation rights in Europe. Facts and Trends, European Trade Union Institute, Report 121, Brussels 2011.

Ekern Steinar, Corporate Governance system in Norwey, Corporate Governance, Winter, 2015/2016.

35 The European Parliament reacted to such processes with a 2009 resolution addressed to the European Commission to take appropriate action to alleviate such tendencies. The Commission was obliged to consult social partners in individual countries to counteract such trends (A. Conchen, Board level..., pp. 31-49). 
Enriques Luca, A Harmonized European company law. Are we there already?, International and Comparative Law 2017/66/3.

Fauver Larry, Fuerst Michael E., Does Good Corporate Governance Include Employee Representation? Evidence form German Corporate Boards, Journal of Financial Economics 2006/82.

Gelter Martin, EU company law harmonization between convergence and varieties of capitalism, 2017, https://ssrn.com/abstract-2977500

Giedrowicz-Niewińska Aneta, Udziat pracowników w nadzorze korporacyjnym w spótce europejskiej, Institute of Economic Research, Working Paper 2015/33.

Gladoch Monika, Uczestnictwo pracowników w zarządzaniu przedsiębiorstwem $w$ Polsce, Wydawnictwo Dom Organizatora, Toruń 2008

Gold Michael, Taken on board: An evaluation of the influence of employee board level representatives on company decision-making across Europe, European Journal of Industrial Relations 2011/15/1

Gomez Pierre-Yves, Wirtz Peter, Successfully mobilizing for employee board representation: Lessons to be learned from post-war Germany, Journal of Management History 2018/24/3.

Hogedahi Laust, Kongshoj Kristian, New trajectories of unionization in the Nordic Ghent countries: Changing labour market and welfare institutions, European Journal of Industrial Relations 2017/23/4.

Jeżak Jan, Ład korporacyjny. Doświadczenia światowe i kierunki rozwoju, C.H. Beck, Warszawa 2010.

Karta Socjalna Wspólnoty Europejskiej, www.ptps.org.pl/old_siteu_miedzynarodowe.php?ustawodawstwo_id=14, 1989

Kim Han E., Ernst Maug, Christoph Schneider, Labor representation in governance as an insurance mechanism, Review of Finance 2018/22/4.

Kluge Norbert, Vitols Sigurt, The crisis: catalyst for stronger worker participation in corporate governance, 2010, http//www.worker-participation,eu/About-WP/Publications/SEEutope-report

Kolvenbach Walter, Handbook on European Employee Co-management, Kluver Law and Taxation Publisher, Deventer, Boston 1987.

Lekvall Per, The Nordic Corporate Governance Model, SNS Forlag, Stockholm 2014.

Levinson Klas, Employee representatives on company boards in Sweden, Industrial Relations Journal 2001/32.

Mallin Christine A. The Nordic Corporate Governance Model, Oxford University Press, Oxford 2010.

Njoya Wanjiru, Employee Ownership in the European Company: Reflexive Law, Reincorporation and Escaping Co-determination, Journal of Corporate Law Study 2011/12/2.

O'Kelly Kevin P., Summary Report and Summing up, in: Kevin P. O'Kelly (ed.), The Role of Worker Directors in the European Union, European Foundation for the Improvement of Living and Working Conditions, Dublin 1996.

Roberts John, Steen Eric J. Van den, Human Capital and Corporate Governance, in: Joachim Schwalbach (ed.), Corporate Governance: A Volume in Honor of Horst Albach, Springer Velag, Berlin 2000.

Rudolf Stanisław, Skorupińska Katarzyna, Bezpośrednie formy partycypacji pracowniczej. Polska na tle starych krajów Unii Europejskiej, Wydawnictwo Uniwersytetu Łódzkiego, Łódź 2012. 
Rudolf Stanisław, Udział przedstawicieli załogi w organach spótki, in: Dorota Dobija, Izabela Koładkiewicz (red.), Ład korporacyjny. Podręcznik akademicki, Oficyna a Wolters Kluwer business, Warszawa 2011.

Szymańska Agata, Włodarczyk Przemysław, Przedstawicielstwo pracownicze $w$ radzie spótki w krajach członkowskich Unii Europejskiej, Studia Prawno-Ekonomiczne 2012/LXXXVI.

Thomsen Steen, The nordic corporate governance model, Management and Organization Review 2016/12/1.

Workers' participation at board level in the EU - 15 countries, Reports on the national systems and practices, Hans Bockler Foundation/European Trade Union Institute, Brussels 2004.

Wratny Jerzy, Partycypacja pracownicza. Studium zagadnienia w warunkach transformacji gospodarczej, Instytut Pracy i Spraw Socjalnych, Warszawa 2002.

Stanisław RUDOLF

\title{
UWARUNKOWANIA ROZWOJU PRZEDSTAWICIELSTWA ZALOGI W NADZORZE KORPORACYJNYM W KRAJACH EUROPEJSKICH
}

\begin{abstract}
Abstrakt
Przedmiot badań: Reprezentacja pracownicza w organach nadzoru korporacyjnego posiada już ugruntowaną pozycję w krajach europejskich. Odnosi się to bardziej do dualistycznego modelu nadzoru, z radą nadzorczą i zarządem, niż do modelu monistycznego z radą dyrektorów. Na rozwój takiego przedstawicielstwa wywierają wpływ władze UE, realizując długofalowe procesy harmonizacji występujących w krajach członkowskich rozwiązań. Rozwój takiego przedstawicielstwa dokonuje się również w krajach skandynawskich pod wpływem realizowanych w tych krajach procesów demokratyzacji. W kilku jednak krajach obserwujemy procesy ograniczania takiego przedstawicielstwa i ma to związek z uwarunkowaniami politycznymi (umacnianiem się partii prawicowych) i trudną sytuacją gospodarczą, spowodowaną kryzysem finansowym z 2008 r.

Cel badawczy: Celem opracowania jest identyfikacja czynników mających wpływ na zmiany zakresu takiego przedstawicielstwa, a także określenie ich skuteczności na wybranych przykładach. Metoda badawcza: Dla osiągnięcia wyżej wymienionego celu badawczego zastosowano metodę krytycznej analizy literatury przedmiotu oraz odpowiednich aktów prawnych. Analizą objęto m.in. teksty publikowane w renomowanych czasopismach dotyczących stosunków pracy (European Journal of Industrial Relations, Industrial Relations Journal), analizowano także problemy z perspektywy prawnej (Journal of Comparative Law Study).

Wyniki: Można ogólnie stwierdzić, że istniejące w ostatnich dziesięcioleciach uwarunkowania sprzyjały rozwojowi bądź umacnianiu się przedstawicielstwa załogi w organach nadzoru korporacyjnego. Pozytywnie należy ocenić próby harmonizacji przedstawicielstwa załogi w nadzorze podejmowane przez władze UE, chociaż ich formalny rezultat jest stosunkowo skromny i ogranicza się głównie do statutu spółki europejskiej. Pozytywne zmiany zaobserwować można było również w krajach skandynawskich, gdzie istniejące uwarunkowania, w tym głównie procesy demokratyzacji, wymusiły modyfikację modelu monistycznego poprzez stworzenie możliwości włączenia do rady dyrektorów przedstawicielstwa załogi. Jednocześnie w wielu krajach zaobserwować można presję na ograniczanie udziału przedstawicielstwa załogi w nadzorze bądź na jego eliminację.
\end{abstract}

Słowa kluczowe: nadzór korporacyjny, reprezentacja pracownicza, modele nadzoru korporacyjnego. 